\title{
RACIALIZED IMMIGRANT WOMEN'S HEALTH STATUS IN CANADA
}

\author{
by
}

Fatima Oine Saliu-Ediagbonya, BA, BSW, York University, 2000

\author{
A Major Research Paper \\ Presented to Ryerson University \\ in partial fulfilment of the requirements for the degree of \\ Master of Arts \\ Immigration and Settlement Studies \\ Ryerson University
}

Toronto, Ontario, Canada, 2008

( Fatima Oine Saliu-Ediagbonya 2008 
I hereby declare that I am the sole author of this major research paper.

I authorize Ryerson University to lend this paper to other institutions or individuals for the purpose of scholarly research.

Signature

I further authorize Ryerson University to reproduce this paper by photocopying or by other means, in total or in part, at the request of other institutions or individuals for the purpose of scholarly research.

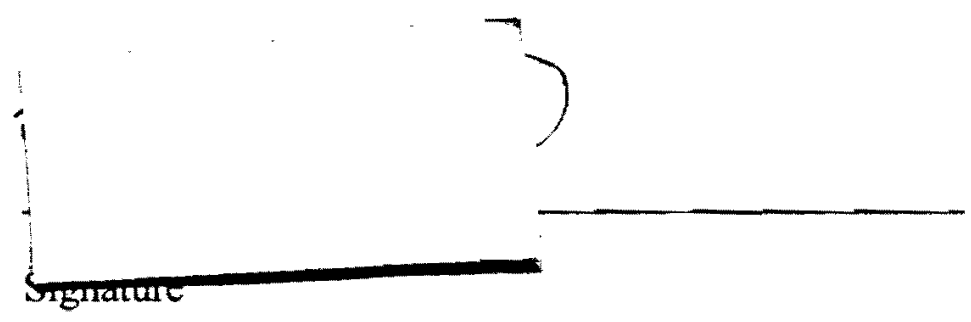




\title{
RACIALIZED IMMIGRANT WOMEN'S HEALTH STATUS IN CANADA
}

C Fatima Oine Saliu-Ediabonya, 2008

Master of Arts

Immigration and Settlement Studies

Ryerson University

\begin{abstract}
Migration benefits both immigrants and the receiving countries. While migrants seek a better life and peace in developed countries, these countries also seek to tap into the human capital of the migrants. Canada, a country which is ranked by United Nation as one of the best countries to live in the world seems to have become the country of choice for immigrants, women inclusive. In order to reap the benefits of migration, good health is therefore important to both migrant and the receiving country. For this purpose, Canada uses a system of medical screening to select healthy immigrants who arrived healthy in Canada but, with passage of time some experience decline in their health. This major research paper therefore, examines the decline in the health status of the racialized immigrant women after their arrival in Canada.
\end{abstract}

Key words:

Immigrant health; racialization and health; healthy immigrant effect 


\section{ACKNOWLEDGMENTS}

I would like to acknowledge the supervision of Dr. Myer Siemiatycki in the preparation of this paper. I thank him for his generous words of encouragement, guidance, support, constructive comments, and suggestions.

I am also grateful to Dr. Wayne Petrozzi for his constructive comments and suggestions.

I would like to thank the entire staff of Covenant House and Sojourn House. My special words of thanks go to Jesus Mejia for being my archive of immigration issues and for sharing his insights.

I am grateful to my friends Dahlia Phillip and Farishta Dinshaw for their words of encouragement, and sharing their insights.

Finally, this paper would not have been possible without the cooperation, prayers, and the encouragement of my Parents, my children, and Odion. I thank them for being my shield, anchor, and stars in my darkest moments. 
To my parents, sisters and brothers, Odion, Margaret, Amen, and Nancy. 
TABLE OF CONTENTS

$\begin{array}{lr}\text { INTRODUCTION } & 1\end{array}$

$\begin{array}{ll}\text { REVIEW OF LITERATURE } & 15\end{array}$

HEALTH AS A FACTOR IN COMING TO CANADA 21

DECLINE IN THE HEALTH STATUS OF THE RACIALIZED IMMIGRANT WOMEN

THE HEALTH CARE SYSTEM AND THE RACIALIZED IMMIGRANT WOMEN IN CANADA

INCLUSIVE HEALTH CARE SERVICES FOR THE RACIALIZED IMMIGRANT WOMEN IN CANADA

CONCLUSION

REFERENCES 


\section{INTRODUCTION}

While several studies have been done on immigrants' health in general, this major research paper focuses on the decline in the health status of the radicalized ${ }^{1}$ immigrant women in Canada based on the phenomenon that has become known as the "healthy immigrant effect" (Kopek, et al. 2001). Literature indicates that the foreign-born, and especially recent arrivals, enjoy better health than their Canadian-born counterparts. "This so-called 'healthy immigrant effect', whereby the health of immigrants is initially high but converges downward to that of the native-born within 5-20years of arrival, has been observed for various outcomes including self-assessed health status, life expectancy, disability and chronic conditions in Canada" (Newbold 2006:2)

The phenomenon is not only observed in Canada, but in other major destination countries for immigrants, such as the United States, Australia, and the United Kingdom where recent immigrants have a significant health advantage relative to comparable native-born populations ( McDonald, and Kennedy 2004; $\mathrm{Ng}$, et al. 2005). The study done in Canada by Newbold (2006) found that $97 \%$ of new immigrants rated their health as good, very good or excellent six months after their arrival, compared with $88 \%$ for the general population. However as time passes, this so-called "healthy immigrant effect" tends to diminish as the new immigrant's health status converges with that of the general population.

Some other literature indicates that non-European immigrant women are found to have generally good states of health when they first arrive in Canada, but fall

\footnotetext{
${ }^{1}$ Racialized immigrant women is described by Canadian Research Institute for the Advancement
} of Women CRIAW (2002) as women who experience racism because of their race, skin colour, 
disproportionately ill after ten years (Chen, 1996; Kinnon, 1999), displaying what is called the "healthy immigrant effect" (Kopec, et. al., 2001). In the Canadian context, according to Newbold (2006) based, on the report by Perez (2002), both recent male and female immigrants were found to be generally healthier than their Canadian-born counterparts in terms of lower prevalence of chronic conditions after adjustment for socio-demographic factors such as age, gender, education and income.

With increasing length of residency in Canada, this health advantage is eroded and accompanied by an increasing prevalence of chronic condition reported within the foreignborn population (McDonald and Kennedy 2004; Perez 2002). The prevalence of chronic condition reported by the immigrants who had resided in Canada for 30 years or more was equivalent to the Canadian-born Perez (2002). In addition to the duration of residency in Canada, Perez also pointed out that differences in health status across immigrant population may result from cohort effect.

This cohort effect is explained simply to mean that more recent arrival may have better health when they entered than their counterparts did when they entered the country at an earlier time (Ali 200; Chen et al. 1996; Dunn and Dyck 2000). According to $\mathrm{Ng}$ et al (2005) immigrants' actual duration of residency in Canada is not available from the National Population Health Survey (NPHS) therefore, for sample size limitations, "two duration categories were created: recent immigrants (10 years or less in 1994/95) and longterm immigrants (more than 10 years in 1994/95)" (Ng et al, 2005:2). For the analysis of their data, they refer to recent immigrants as those who arrived in 1984 or later and the minorities who are targets of racism. 
long-term as those who came before 1984. Their analysis also included both recent and long-term Europeans and non-Europeans.

The study that followed initially healthy individuals across five waves of longitudinal data from the National Population Health Survey (NPHS) indicated that between 1994/95 and 2002/03, data for all aggregated immigrants to Canada showed them to be at higher risk of deterioration in health status than the Canadian-born. In addition, the new analysis of five cycles of (NPHS) data which distinguishes between European and non-European immigrants, shows that the difference is "attributable to those from nonEuropean countries, who are twice as likely as Canadian-born to report a deterioration in their health-that is, they had rated their health good, very good or excellent in 1994/95, but subsequently described themselves as being in fair or poor health" (Ng et al, 2005:3).

Moreover, recent immigrants from non-European countries, who arrived in Canada between 1984 and 1994, were twice as likely as Canadian-born people to report deterioration in their health (Statistics Canada: The Daily (2005:1)) The study also indicates that, the greater likelihood of becoming frequent visitors to the doctor (at least six consultations a year) by recent non-European immigrants serves as an indicator of the deterioration of their health $(\mathrm{Ng}$ et al, 2005). The study further suggested that, "a concomitant increase in the frequency with which recent non-European immigrants consult physician suggests that the loss of health was real, and not merely an artefact of cultural or subjective differences in the perception of health status. This finding seems to be problematic as reasons for hospital visits were not indicated.

Several authors also carried out studies that supported the notion of the "healthy immigrant effect" and indicated that, foreign-born populations have superior health 
profiles compared to native-born populations (Ali, 2002; Mckay, Macintre, and Ellawy 2003; Pérez, 2002). However a new dimension set in with the recent evidence suggesting that the effect may be more apparent than real, with only limited support for the effect observed with respect to self-assessed health status while support for the "healthy immigrant effect" has been found with respect to chronic conditions (McDonald and Kennedy 2004; Newbold 2005). .

This phenomenon has also become generally accepted as a benefit to both immigrant men and women but, Chui (2003) claims that there is a relationship between gender and immigrants health. In addition, according to Hyman (2001) the new researches on health transition pointed to immigrant women, low-income immigrants, and non-European immigrant as at high risk of transitioning to poor health. It seems that not all immigrant population is able to keep this protected health after they arrive in Canada

While the "healthy immigrant effect" has been confirmed within the literature, the study that used longitudinal data potion of the National Population Health Survey (NPHS) changed this view as it carried out its own study from the perspective of chronic condition. The two conclusions that emerged from this study according to Newbold (2005) are that, there is no evidence of "healthy immigrant effect" with respect to self-assessed health status, and there was evidence with respect to chronic condition, and that " females were significantly at a greater risk than males of experiencing at least one chronic condition over the period. The research gap or short coming from this study according to Newbold (2005) is that the (NPHS) is limited given its inability to distinguish between immigrant types.

However an important limitation of literature on immigrant health must be noted. There is very little work looking in focused way at the experience of specific immigrant 
sub-sets either by country of origin, age or gender. Rather most of the writing on this topic deals with immigrant health in broad aggregate analysis. This makes it difficult to present evidence comparing data for different groups of immigrants. This study therefore draws upon both generic immigrant health research, as well as the writing of academics and organizations working from anti-oppressive perspectives.

As there is very limited evidence of chronic conditions established in the literature that were reviewed, this paper therefore focuses on the decline of the health status of the racialized immigrant women. My particular interest is on the racialized immigrant women who may be at greater risk of transitioning to poor health. The racialized population groups may likely stand the chance of being at high risk of poor health after arriving in Canada, as link between socio-economic status and health has been established by some authors such as Galabuzi (2001) and Ornstein (2000).

This major research paper therefore uses past studies of immigrant women's health to examine the extent to which the intersection of gender, race, and class account for the gradual erosion of the "healthy immigrant effect" of the racialized immigrant women. Seeking to know this is important since immigrants will not function in isolation but within various structures of the society such as economic, political, and other social structures including some other institutions of the society.

Above all, we must also bear in mind that the "forces of race and gender clearly determine the economic, social, political, and the environmental components of class status that shape health status" (Bayne-Smith 1996:36). What is unsettling about this phenomenon is that Canada is a country that has universal health care system, and while some recent immigrants are expected to experience health problems upon their initial arrival based on 
migration and settlement related stress, they are also expected to bounce back by having and maintaining better health upon settlement.

The Employment Equity Act of 1986 defines visible minorities as "persons, other than Aboriginal peoples, who are non-Caucasian in race or non-white in colour." Under this definition, the regulations to the Act specify the following groups are visible minorities: Chinese, South Asians, Blacks, Arabs, and West Asians, Filipinos, Southeast Asians, Latin Americans, Japanese, Koreans, and Pacific Islanders. In the 1996 census, the identification of the racialised group population was achieved using a new census question that asked respondents whether they were members of one of the population groups defined as a visible minority under the provisions of the Employment Equity Act.

For the purpose of this Major Research Paper, I choose to use the word racialized and this is not chosen or used loosely but because it is "commonly used by women to refer to their identity, stigmatization, and ostracism as a discrete racial category characterized by traits or attributes that were thought to be typical" (Andermahr, 2000:222). In addition, I choose to use the term racialized as it describes and refers to the various types of oppression that some immigrant women have experienced as claimed by Andermahr (2000).

It is also important to bear in mind that, Canadian Research Institute for the Advancement Women (CRIAW) (2002) described racialized immigrant women as women who experience racism because of their race, skin colour, ethnic background, accent, or women of color from different ethnic, linguistic, religious, or cultural minorities who are target of racism. All these characteristics are the identities which have been socially constructed for them and they are very marginalizing, yet they have to live their daily lives 
interacting with the dominant groups/ideologies in all spheres of life being it political, social or economical. It means that some immigrant women from this segment of Canadian population may be more likely to contend with deteriorated health because of their socioeconomic status.

Health is also said to be "detrimentally affected by gender role statuses as they interact with economic disparities... these conditions result in an unfair health burden, in particular, for women whose access to health determinants is in various degrees limited" ( Beiser 2005:1). Examining the gradual erosion of the "healthy immigrant effect" leading to the declined health of this group of immigrant women in Canada will be done by examining the extent to which gender, race, and class intersect with the health determinants to affect the health advantage of racialized immigrant women in Canada. This work will be based primarily on several studies that have been done, on the health status of immigrant women in general. My sources of information include academic journals, text books, government reports, and Community Health Care Centre reports as made available to the general public.

The evidence supporting the "healthy immigrant effect" tends to have been accepted internationally with two dimensions to it. The first dimension is the immigrants' better state of health upon arrival in relation to the natives' state of health between 5-20 years. This study did not consider other natural life cycle such as old age. The gap between the arrival period and the period when the health advantage is lost is rather too wide. Loss of health advantage may therefore be taken as a natural response to life cycle. However, the management and the coping mechanism may differ for individuals based on differentiated social and economic location in the society. 
The second dimension of the "healthy immigrant effect" is the worsening of the immigrants' state of health. Some authors refer to this dimension as the effect of Years Since Migration (YSM) which is expected to be evident as the recent immigrants tend have a health advantage over long-term immigrants, that is, a decline in the "healthy immigrant effect," with longer periods of residence in Canada, leads to the worsening of immigrants' state of health. (Kennedy and McDonald, 2004). There are various explanations offered for these two dimensions in the existing literature and they will be examined as the paper progresses.

According to Schimmele and $\mathrm{Wu}(2004)$ this health advantage includes lower mortality rates, fewer chronic conditions, fewer disabilities, and overnight hospitalization, and less mental illness. Meanwhile, McDonald, and Kennedy (2004) claim that the "healthy immigrant effect" is present even though a majority of immigrants come from developing countries where mortality or morbidity indicators are higher than the developed countries to which they are migrating. Interesting, one would expect some new immigrants to exhibit poor state of health upon arrival to Canada, not only because of their county's condition but because of the migration and settlement related stresses.

In examining the seeming contradiction, above, there are three main explanations that have been offered: health screening by recipient countries, healthy behaviour prior to migration followed by the steady adoption to the new country's healthy behaviours and immigrant self-selection where healthier and wealthier people have come to be migrants. In addition to the above explanation is the length of residence in Canada, YSM, as defined by Kennedy and McDonald (2004). All the above explanations will be examined. 
The paradox of this phenomenon is unsettling for me as an immigrant woman and as a student of Immigration and Settlement Studies; it is worth examining. How can some immigrant women lose their health advantage after arriving in Canada? Canada is a country with high standard of living and with a system that promises universal access to high quality health care (Beiser and Stewart, 2005) yet there continues to "remain a great deal of variation in the health status of those living in Canada even though the Canada Health Act was developed with a focus on "equalizing" health status by "equalizing access to services which were once thought to be the prime determinant of health" (Commission on the Future of Health Care in Canada 2002, p.5). Moreover, Beiser and Stewart, (2005) claim that the variation in the health status is not randomly distributed.

How can this happen in a country that is committed to equity and access in health care and opportunity? As Canadian Council for refugee notes, in Canada , "[o]ptimal care is thought to be based on the core values of access, inclusion, empowerment, user-defined services, holism, respect, cultural sensitivity, community development, collaboration, accountability, orientation towards positive change, and reliability" (Canadian Council for Refugees 1998).

This is unsettling for me because, "undoubtedly, immigration involves individuals, families . . immigrants responding to two sets of factors - the 'Push' factors that drove emigrants away from their home country and the 'pull' factors that lured immigrants to the country of destination" (Li, 2003 p.14). Canada has a reputable image in the world. The United Nations (2004) ranked Canada the highest in the Human Development Index, portraying Canada to the whole world as the best country in which to live. This might have served as both pull and push factors for immigrants' choice to migrate to Canada. 
The group of my focus for this study is racialized immigrant women because "at no time in human history have women been on the move as today. About 90 million women currently reside outside their countries" (Zlotnik 2003:6). In general, "ethno-racial minority group member-other than Aboriginal persons make up 13\% of Canada's population" ( Fact Sheet 3 1, Understanding the Racialization of Poverty in Ontario An Introduction in 2007). There are increasing numbers of women who migrate on their own as the principal wage earners for themselves and their family according to Zlotnik (2003). .

My interest in this population is based on what the literature indicates in terms of the differences in the level of the benefit of the "healthy immigrant effect" between immigrant men and women in general. Exploring the extent to which the intersection of gender, race, and class affect the health advantage of racialized immigrant women is therefore important.

It is particularly important to examine the factors that contribute to the loss of the health advantage of the racialized immigrant women as, "it is becoming clear that one major element of inequality of immigrant women is due to the fact that a large proportion of immigrant women are racialized" (National Organization of Immigrant and Visible Minority Women, 2004:11). Why and how a particular group is racialized in Canada will be examined.

For the purpose of this work, an immigrant woman is defined as a woman, "who moves to Canada with the intention of staying permanently. Immigrants [women] come from all over the world-Europe and third world countries. Immigrants can be white or people of colour, speak English, French or another language as a mother tongue" 
(Canadian Research Institute for the Advancement Women (CRIAW), 2002). The focus of this paper is not on all immigrant women, as immigrant women's experiences are diverse.

My interest in the health of racialized immigrant women arises from my deep understanding of the various settlement issues faced by less established immigrant populations in Canada as a graduate student of Immigration and Settlement Studies, including my work experiences with this population as a settlement worker that exposed me to their various health problems. In addition, my interest to learn more about the health problem of the racailized immigrant women developed further during the period of my student placement with "Women's Health in Women's Hands"- a Community Health Care Centre, located in Toronto that provides services to women from Africa, Caribbean, Latin America, and South Asia-population groups identified by Women's Health in Women's Hands (WHIWH) as at risk group.

With the passage of time, my interactions and various involvements with these populations did not only give me a deeper insight into their health issues but also helped me to become aware of my own social location including my various entitlements in Canadian society as a Canadian citizen, which I had come to take for granted. For instance. I am a resident of the province of Ontario, in possession of the Ontario Health Insurance Plan, speak English and understand the internal working system of the health care. I am able to see a doctor, even for a common cold. In addition, I am employed and in possession of an extended health insurance plan. This means I am able to seek alternative treatment and capable of shopping for doctors.

It made my heart bleed to observe the patterns of health inequalities of racialized immigrant women and refugee women. These are people with various kinds of health 
problems, as serious as HIV/ AIDS, and other health related issues who seemed to have found haven in this community health centre. Through my various interactions with them, I now understand that most of these clients chose this centre because it offers them relatively easy access to health care, as opposed to the mainstream medical facilities where the clients claimed they often encounter barriers to health care services. I suspect therefore, that my perspective and analysis of my findings in this paper is influenced by my identity and specific social location as a black immigrant woman.

What is significant about the characteristics of this population is that they are racialized women, minority women and women of color are disproportionately poor. All these characteristics further marginalized them in Canadian society at large. In addition to this marginality, they also have health related problems ranging from chronic illnesses to health problem as serious as HIV/AIDS as evident in their services eligibility assessments. The clients of the Women's Health in Women Hands Health care centre truly represent the racialized immigrant women in Canada and this is the reason why I decided to know more about the health issues of the racialized immigrant women in Canada.

For the above reasons therefore, it is not likely that all immigrant women population would have health issues or experience health deterioration, but those who are marginalized in Canadian society at large. This is in agreement with some authors who claim that, there is certainly a link between poverty and health as review of literature reveals the general agreement that poor women of color's experience structural barriers to treatment serves to exacerbate their higher experience of serious illness. (Cooper, 2002; Tharao \&Massquoi, 2001; Kumanyika, Morssink, \&Nestle, 2001). While some women in 
general might experience health problems, the marginality of the racialized immigrant women might further complicate their health issues.

This research will be pursued by addressing some research questions that will offer some insights into why some groups are at a greater risk of a diminished or eroded, "healthy immigrant effect" that they have enjoyed upon their initial arrival in Canada. The questions are as follows:

1. What are the existing explanations for the phenomenon of the "healthy immigrant effect?"

2. Is health status a factor in migrating to Canada and what happens to immigrants' health status after migrating to Canada?

3. The Canadian health care system is universal but, to what extent is it inclusive to the racialized immigrant women?

This paper will analyze the various competing explanations regarding the existence of the "healthy immigrant effect". This analysis will be followed by the analysis of policy around the health screening of immigrants seeking to migrate to Canada. It will also examine what happens to their health, upon settling in Canada, by exploring the various health determinants as they affect the health status of racialized immigrant women leading to the gradual erosion of their "healthy immigrant effect" hence, their worsening health status.

Finally, there will be the analysis of the health care system, paying attention to the mainstream model of health care services in general to explore to what extent it is alienating to racialized immigrant women, and suggestions will be offered for the type of health care services that will best meet the health care needs of racialized immigrant 
women in Canada. This is important, bearing in mind that "holistic" approach to health care provision is in keeping with the view that health care must involve not only an understanding of woman's biology but also of her social, political and emotional environment (de Aguiar, 2001; Williams, 2002; Women's Health in Women's Hands, 2004 a).

The questions posed in this major research paper are also intended to help sensitize the health care needs of this segment of the Canadian population and for their health care needs to be examined on a systematic basis. While this project is not a means to an end in itself, its purpose is to draw the attention of policy makers, services providers and the general public to the health care needs of the racialized immigrant women in Canada., in order to minimize the human and economic cost of illnesses. 


\section{REVIEW OF LITERATURE}

Zlotnick (2003) notes, that one of the most significant trends in immigration is the entry of women in the migration system that was for several decades, dominated by men. Zlotnick explains further that, while many women accompany or join family members, increasing numbers of women migrate on their own and a significant number are forced migrants who have fled conflict and other situations that affect their lives in general. Carey (1997) however identifies various routes to Canada which include: regular immigrants, refugees and protected persons, temporary residents (visitors, workers, students, and temporary resident permit holders) and sponsored family class. Carey further contends that, there is a hierarchy of entitlement and rights based on a person's immigration status (1998).

There is a consensus among researchers that the "healthy immigrant effect" exists across all immigrant groups in all four destination countries--United States, Canada and Australia and the United Kingdom studied to offer an explanation for the phenomenon of the "healthy immigrant effect" in which immigrants enjoy significant health advantages relative to comparable native born populations in these countries (McDonald, and Kennedy, 2004). The relatively good health of recent immigrants from developed countries has come to be known as the "healthy immigrant effect". The authors claim that the "healthy immigrant effect" is present even though a majority of immigrants come from developing countries where mortality or morbidity indicators are worse than the developed countries to which they are migrating. 
The evidence supporting the "healthy immigrant effect" tends to have been accepted internationally, and generally accepted to have two dimensions to it. The first part is the immigrants' better state of health upon arrival in relation to the natives' state of health, and the second part is the worsening of immigrants' state of health after they arrive in Canada.

The first dimension of the "healthy immigrant effect" is the immigrant's better state health upon arrival in Canada in relation to the native's state of health is consistently in agreement with some of the explanations offered by McDonald and Kennedy (2004) in support of the existence of the "healthy immigrant effect" as explained below, and the second part, the worsening of immigrants' state of health will be explained in the later part of this paper.

The idea that immigrants are positively selected among their origin population meaning that, healthier persons are physically or financially more able to migrate as claimed by (McDonald and Kennedy, 2004), seems appropriate as Canada's immigration selection processes often searches for "younger and better educated immigrants who may also be better able than older, less healthy immigrants to cope successfully with the physical, psychological and sociological challenges of immigration" (Gushulak ${ }^{2}$, 2007:1439). If both migrants and the receiving counties are to benefit from migration, it is the healthy migrants that will be able to maximize the benefit of their investments in migration. In addition, the receiving country will go for the healthier immigrants in order to meet the objective of immigration whether it is for population growth or for human capital.

\footnotetext{
${ }^{2}$ Gushulak, Brian has focused on international health and migration for the past two decades in Canada and in abroad. He is now engaged in research and consulting in the area of health and population mobility.
} 
Jasso et al (2004) in support of Gushulak's idea, contend that according to the neoclassical economic theory, migration is seen as an investment in human capital where the young, the more educated, and the healthier are in general more able to reap the reward of their investment and therefore more likely to migrate. And according to some authors, this theory is to be taken as a given based on the strong positive relationship between income and health that have been conclusively documented in the literature (Powles, 1990, Khlat and Darmon, 2003)

In addition, for instance, Canada uses the point system to assess all independent and skilled workers applicants to Canada. Some of the factors that are considered in the point system are education, abilities in English or French language, and age. Education for instance is calculated at 25 points according to Citizenship and Immigration Canada (2007). Immigrants form third word countries who met the required points for education, are most likely to be affluent. Since there is a link between wealth and health, the wealthy immigrants who are selected to come to Canada are most likely to arrive in Canada healthy

Gushulak (2007) further claims that healthy behaviour prior to migration is a contributing factor to "healthy immigrant effect". This is true even though many immigrants tend to be from regions of the world where lifestyle-associated behaviour contributes to chronic diseases. Obesity, associated with inactivity and diet, for example, are less prevalent in the Third World than those observed in the developed world. For example, "China and Africa the two source regions for immigration, boast the lowest rates of obesity ${ }^{3}(<5 \%$ of the population) this observation suggests that immigrants should be less prone to obesity than Canadians in general" (Beiser, 2005:S34).

\footnotetext{
3 "Obesity is linked with type 2 or non-insulin dependent diabetes, a condition affecting 177 million people around the world, and implicated in approximately 4 million global death per year" (Beiser.
} 
Health screening is also attributed to the "healthy immigrant effect," For admission into Canada where immigrants must meet certain health criteria as stipulated in the Immigration Act of 1976. (Longitudinal Survey of Immigrants to Canada). However, Laroche (2000) claims that the percentage of applicants to Canada that are rejected on health ground is very low.

In support of the above, for instance, to meet Canada's humanitarian commitments and international obligations, Canada is required to protect refugees and others in need of protection. Therefore, refugee claimants are not refused admission to Canada on the ground of their health status deemed to cause excessive demand on Canada's healthcare system or deemed to pose danger to public health or safety to the general public as maintained by Citizenship and Immigration Canada (2001-2002).

In addition, Uitenbroek and Verhoeff (2002) view the explanation, based on selection by authority, as not convincing in their study of the mortality of Mediterranean immigrants to Amsterdam. Meanwhile, Jasso et al. (2004) argue that the appropriate comparison with which to gauge the "healthy immigrant effect" should be between immigrants and similar people in the source countries. Comparisons, they contend, should not be made with native born people from the host countries.

In respect to morbidity and all causes of mortality rates, some Canadian literature indicates that immigrants in general compare favourably with domestic-born persons. (Hyman 2001; Pérez2002). For instance, it has been confirmed that the average life expectancy at birth for the Canadian-born is roughly 74 years for men and 80 years for women (Chen, Wilkins, and Ng 1996). By comparison, the life expectancy for European immigrants to Canada is about 76 years for men and 82 years for women. Non-European 
immigrants have the longest life expectancy, with the men expected live to 80 years and the women 86 years.

The above findings again, illustrate the paradoxes in the literature. If the nonEuropean immigrant women have longer life expectancy than both Canadian-born population and non-European men, they are most likely to be in good health. More research is required to determine how this finding can be consistent with the consensus on the deteriorated health of immigrants after their arrival in Canada

In regards to the theory which claims that favourable habits and behaviours in the home country prior to migration lead to potential immigrants being relatively healthier than the average person in the recipient country some authors claim that pre-migration life in developing countries involves a high level of physical activity and low fat/low calorie diets, and explain further that, this behaviour is more conducive to general good health. (Powles, 1990, Khlat and Darmon, 2003)

However, International Organization for Migration, (2002) notes that migration can profoundly affect the health and well-being of not only the women who migrated internationally, but also those who migrate within the regions of their countries, and that to determine the extent to which women's health is affected is complex. It involves an interaction of broader determinants of health (including access to healthcare services) and the types of illnesses to which they are exposed. In addition, Hyman in her report entitled, "Immigration and Health" indicated that immigrants' health is shaped by their environment and their living condition. Furthermore, she wrote, that it changes over time in response to the pressures of poverty, marginalization, and class inequity (2001). 
The length of residence in Canada is also attributed to the health advantage for immigrants. Kennedy and McDonald (2004) refer to the length of residency as Years Since Migration (YSM) and claim that it is expected to be evident, with recent immigrant having a health advantage over long-term immigrants, that is, a decline of "healthy immigrant effect" over longer length of residence in Canada. In support of this however, Canada's National Population Health Survey data recorded, for example, those immigrants who had been in Canada, for ten years or less, had fewer chronic conditions and less disability than either native-born Canadian or long-term immigrants. The health of longer stay immigrants was, however, similar to that of the general population.

However, the duration in the host country needs to be studied further as a determinant in dimensions of the "healthy immigrant effect". According to Perez, (2002) there is a gap in the literature that represents a serious conceptual limitation because the current information suggests that this health advantage is concentrated among recent arrivals from non-traditional source countries. For instance, according to $\mathrm{Ng}$ et al (2005) deterioration in health applied only to immigrant with non-European origins especially those who had arrived since the mid -1980 s. And Perez (2002) went on to say that this observation forces us to contemplate whether the healthy immigrant effect is, indeed, a reliable general concept. The effect may be a temporary phenomenon, attenuating or disappearing over time and is perhaps peculiar to specific ethnic sub-groups of the immigrant population.

Morris (2004) asserts that while there seems to be general agreement that both sexes keep the same pattern of the healthy immigrant effect in terms the length of residency in Canada, poor mental health is more prevalent among women compared to 
men. In effect, while the difference with Canadian-born persons is not statistically significant, long-term immigrant women suffer the most from mental health problems. In addition, Morris wrote that immigrant women are more concerned about their emotional and mental health than the traditional risks of tobacco, drugs and alcohol.

Medical screening of applicants and the requirement to be healthy partially explain the high degree of good health among immigrants, as several authors claim that it is perplexing and contradictory that newcomers demonstrate a high rate of robust mental health. They further indicate newcomers are most likely to be vulnerable to depression as a result of migration related stress. This may only be true with some immigrants that might have been pushed or forced out of their countries. They are likely to suffer more loses than those who chose to migrate who had enough time, money, and the good health to migrate. This group of immigrants may face less migration and settlement related stress (Berry, Uichol, and Minde 1987; Finch, Kolody, and Vega 2000; Noh and Avision1996; Rogler, Cortes, and Malagady1991).

\section{HEALTH AS A FACTOR IN COMING TO CANADA}

Health screening of immigrants is an important factor to Canada as it tends to manage the threat and risk of migrant imported infectious diseases. Health is also an important factor to the migrants. As we saw earlier, Jasso (2004) refers to the neoclassical economic theory, which views migration as an investment in human capital. Jasso describes the theory as where the young, the more educated, and the healthier people are, in general, more able to reap the reward of their investment and therefore more likely to 
migrate (2004). Therefore, in order to reap the reward of their investment in migration, health will seem to be very important for immigrants.

As for the recipient country, the health of immigrants is equally important especially for countries that depend on immigrants for their economic, and population growth. Gushulak, (2007) claims that much of the historical focus on health and migration has compared characteristics between immigrant and host population. Traditionally, this approach was centred on managing the threat or risk of migrant-imported infectious diseases, such as plague, cholera and tuberculosis.

For example, in order to be admitted into Canada, immigrants must meet certain health criteria as stipulated in the Immigration Act of 1976 (Longitudinal Survey of Immigrants to Canada). Prior to coming to Canada, the immigrant must demonstrate to be in good health. Foreign nationals are inadmissible on health grounds if their health condition "is likely to be a danger to public health, is likely to be a danger to public safety and might reasonably be expected to cause excessive demand ${ }^{4}$ on health or social services" (Citizenship and Immigration Canada ENF 1 Inadmissibility A38(1)(b); A38(1) a38(1)(c)).

Gushulak (2004) further claims that the perceptions that immigrants will import diseases continue to be reflected in immigration policy. These fears were augmented, early in the last century; by political and social perceptions that certain immigrant groups were at high risk for importing behavioural disorders, chronic diseases and non-infectious conditions that were claimed to be more common in some immigrant groups. Historically,

\footnotetext{
${ }^{4}$ Excessive demand clause is that applicants will not be admitted "if their health demands exceed that of the average Canadian evaluated as $\$ 2,500$ per year, if their admission may displace a Canadian resident from obtaining services, or if the required services are not available and/or accessible"(Laroch, 2000:53).
} 
it was feared that people of colour would bring strange diseases to Canada and the fear was even used to rationalize their exclusion as citizens (Anderson and Kirkham, 1999).

Further, some authors contend that the fear continues to exist and tends to have influenced policy decisions around screening mechanisms for the detection of diseases among potential immigrants, is an approach which is based on the medical evaluation and screening of immigrants which is aimed at identifying those with disease or condition and preventing their admission (Beiser, 1998; Shroff, 1996).

However, the medical screening of those intending to immigrate to Canada is only limited to the time of the immigration process and the immediate period of arrival. The health determinants affecting immigrants' health before their arrival, during transition, and in the long term after their arrival did not receive enough attention and policy consideration according to Gushulak, (2007). Upon arrival in Canada, immigrants must integrate into Canadian society, and their successful integration is likely to be determined to a large extent by their socio-economic status. We must also bear in mind that "the forces of race and gender clearly determine the economic, social and the environment of class status that shape health status" (Bayne-Smith 1996:37).

Based on the above claim, Coming to Canada is not an assurance that all other underlying factors that may make people to become more vulnerable to some existing diseases will be eliminated because of the universal health care system. According to Bolaria \& Bolaria (1994) genetic, biological, and behavioural factors that expose individuals or prevent them from diseases operates within a social context such as income, education, occupation, age, gender, material status, living condition, and stress to some extent determine the extent to which an individual will be at risk for illness or diseases. 
They also emphasized that though the variations in health are determined by the above mentioned social factors, but they are not randomly distributed.

Though, Immigration and HIV/AIDS (2004) describes immigration status as a "Ladder" with Canadian citizens on top of the heap with the most rights. Each status has certain rights and obligations but, contrary to Gushulak's contention regarding lack of attention for the health determinant of immigrants after their arrival, Canada's immigration selection is on basis of attributes such as education, job, skills, and youthful age, all of which are "grouped under the rubric of human capital. Screening helps ensure that they are healthy as well. After immigrants enter the country, responsibility for assuring they stay healthy devolves to the province" (Beiser, 2005:\$30).

Canada's concern for the health care of its residents is manifested in a national health insurance programme which is colloquially known as "Medicare." The program is administered through 13 independent provincial and territorial health insurance plans tied together under the authority of the Federal Canada Health Act. The programme is designed to ensure that all residents of Canada have access to medically-necessary hospital and physician care on a prepaid basis" (Wong, 2003:10).

Canada's universal health care system exists to take care of the health care needs of its insured residents. Regardless of any political debate about Canada's healthcare system, Canada does boast of the highest life expectancies (about 80 years) and lowest infant mortality rates of industrialized countries. (Canadian Health Care, 2004). Many attribute this high quality of life to Canada's health care system. However "health is a complete state of physical, mental and social well-being and not merely the absence of disease or infirmity. Specifically, women's health involves their emotional, social and physical well- 
being and is determined by the social and economic context of their lives as well as by biology (Canadian Women's Health Network (2005).

However, what seems to be at stake here are the health disparities that continue to exist in Canada and this paper therefore seeks to know about the factors that contribute to the decline of the "healthy immigrant effect" of the racailized immigrant women. For instance, "some women are more prone to ill health and early death than the others: Gender interacts with race, disability, income, environment, genetics and a number of other characteristics" (CRIAW, 2005:1). This is even more important than knowing how the health care system in Canada meets the health care needs of individual, because "medical intervention can only attempt to cure individual disease symptoms presented to the health, or more appropriately, 'sick' care system, and hence tends to neglect the prevention of illness" (Bolaria \& Bolaria 1994:11). The next chapter will then be devoted to the factors that lead to the decline of racialized immigrant women's health.

\section{DECLINE IN THE HEALTH STATUS OF THE RACIALIZED IMMIGRANT}

\section{WOMEN}

It is suggested that recent immigrants from non-European countries, who were "initially healthy in $1994 / 95$, adopt some unhealthy lifestyles in the process of adapting to a new culture. Indeed, the study found that these immigrants were almost twice as likely as Canadian-born to have a $10 \%$ or more increase in their body mass index" (Statistics Canada: The Daily2005:1). The study explains further, that the measurement index is to determine a person's weight relative to his or her height. An increase in the index reflects a weight gain, which might be harmful for one's health. Doctor's visits in excess of six times 
per year by recent non-European immigrants were used as an indicator of higher risk for poor health. Reasons for visiting doctor were not given in the research finding.

However, some studies indicate that non- European immigrant women were found to have generally good states of health when they first arrive in Canada, but then fall disproportionately ill after ten years (Chen, 1996; Kinnon, 1999). While the phenomenon of the "healthy immigrant effect" has become generally accepted as a benefit to both men and women there is a relationship between gender and immigrants' health (Chui, 2003). Several explanations are offered for these relationships, as examined below.

Canada's rigorous immigration selection policies account for the "healthy immigrant effect" paradigm where the selected immigrants are portrayed as the cream of the world's crop. Explaining further, Beiser contends that, following the above framework, if an immigrant becomes ill as they resettle, it is likely "due to convergence" and/or resettlement stress"(2005:S31). Beiser, also attributes this resettlement stressor to the interaction framework that sees health outcomes as the result of the interacting processes which includes predisposition that may be generic, or pre-migration exposures and experiences, including post-migration stressors and individual and social resources (Beiser (2005).

Following, Beiser's convergence and or resettlement framework, for instance. acculturation $^{6}$ is one of the explanations offered by Beiser for the decline of immigrant's health status. Kennedy and McDonald (2004) claim that immigrants take up unhealthy

\footnotetext{
5 "Convergence is a process through which, because immigrants are exposed to the health risk that are encountered by resident Canadians, their good health declines to the more mediocre Canadian average" (Beise 2005:S31).

"Acculturation is the process resulting from inter-group contact, during which individual, whose primary learning has been in one culture take on characteristics (attitude, values, and behavior" (2005: 5).
} 
lifestyles and behaviours such as smoking and alcohol consumption upon settlement in their host country. They further explained that, there is the possibility that the immigrants's attitude towards what constitutes good health can evolve over the years living in the host country. However Newbold (2005) cautioned that acculturation could also mean taking on positive behaviour such as community participation, among others, which may be associated with improved health outcome.

Gushulak (2007) contends that, the deterioration of healthy characteristics stems from both behaviour and environment changes. Furthermore, acculturation takes the form of changes in diet, level of activities and the use of medical services. "Increased body mass index, altered glucose metabolism and behavioural changes (for example, use of tobacco, alcohol or other substances) following arrival may increase the risk of adverse health outcomes, and some of these factors are known to affect maternal, and child birth" (2007:1439).

To help explain the decline of immigrant health, Beiser (2003) who focuses on the convergence premise, claims that, physical, social, cultural and environmental influences in the destination country do set in motion the process in which immigrant patterns of morbidity and mortality change and come to resemble the (usually worse) health pattern of the resettlement country.

The years since arrival, is one of those explanations that have been generally accepted to account for the deterioration of the immigrant's health advantage. It has been observed that the longer immigrants live in Canada, the more their health resembles that of the Canada-born population. For example, Vissandjee et al (2004) claim that recent immigrant women, with 2 years or less in Canada, are less likely to report poor health than 
Canadian-born people,. While, those who have been in Canada for more than 10 years are more likely to report poor health as their health advantage decreases over time.

For instance, Beiser (2005) cites an example with respect to diabetes in which the studies suggest that diabetes-free immigrants develop the disease rapidly after resettlement. Immigrant rates of diabetes do not, however, converge with majority population norms, they overshoot ${ }^{7}$ them. For instance, South Asian immigrants in Canada have higher rates of type 2 diabetes than native-born Canadians.

Another example cited by Bieser is the Canadian data about cancer among Italian migrants, and their offspring, that are more consistent with the convergence model. The data indicates that the first-generation Italian immigrants have low rates of colon, lung, and breast cancers. These diseases have an etiology strongly embedded in environmental factors. Rates of illness among their offspring are midway between those of their immigrant parents and members of the receiving society. Beiser also cited a report of Balzi et. al on dose-report effect, and claims that this report indicates that the risk of immigrants developing colon cancer increases with increasing length of time in Canada.

More so some authors claim that United States statistics for death resulting from diabetes also indicates 52.9 per 100,000 deaths for black women versus 17.2 deaths for white women. Heart disease, in the US, is 224.6 per 100,000 for black women versus 92.2 per 100,000 deaths for white women. They also claim that this racial imbalance is also indicated by the statistics in Canada as there is a rising number of women of colour diagnosed with HIV/AIDS. in Canada. (Kumanyika, Morssink, and Nestle, 2001). There is

\footnotetext{
${ }^{7}$ Overshoot occurs when resettlement accompanied not just by rates of illness equal to those found in the receiving society but even higher. Bieser (2005)
} 
the need therefore to address this imbalanced statistic in which black women in Canada are disproportionately affected by HIV/AIDS.

For instance, emerging data indicates, "more than $70 \%$ of all maternal HIV transmission in Ontario was among African and Caribbean women. In 1996 the African and Caribbean women accounted for $32 \%$ of AIDS related deaths among women in Ontario" (Canadian Women's Health: The Network, 2005:13). Women of colour are the "least visible among AIDS patients" (Reid, 2000:287). Reid, Pequegnat and Stover (1999) assert that, "women of colour have a constellation of problems based on demographic, economic, and health factors that put them at an increased risk for HIV and for a poorer prognosis following diagnosis of HIV disease" (p. 287).

All the above mentioned factors seems to be pointing towards all the predisposed factors such as genetic, biological, and behavioural that causes illness according to Bolaria \& Bolaria (1994) who also claim that it is the social circumstances of individuals that "set the stage upon which these factors act" (1994:11). We should be careful so as not to over emphasize this, to avoid laying excessive blame on the victims. "Blame the victim policies assume that individuals alone can control their health destiny without consideration of their economic capacity to do so or the availability and the accessibility of health services" (Bayne-Smith, 1996:6).

In order to avoid this victim blaming game, it is vital to consider the stratified nature of Canadian society and how it affects the entire life of the racialized immigrant women. According to Bayne-Smith (1996) the location of the racialized women in the structural hierarchy is based on race, gender, and class. And that all these identities place restrictions on their social mobility. This restriction in terms of education, employment, 
and housing also have negative impact on their life chances as in the area of health more than any other sphere of life, the structural restriction of race, gender, and class become linked to life and death.

In the light of the above claim, some literature tends to point to some social factors that may directly or indirectly link to the general socio-economic factors that have a serious effect on health status as noted by Bolaria \& Bolaria (1994). The International Organization for Migration (IOM) is one of those literatures that notes that, determining the extent to which women's health is affected is complex as it involves an interaction of broader determinants of health (including access to health care services) and the types of illnesses to which they are exposed.

In addition, Hyman (2001) in her report, "Immigration and Health," indicates that their environment and their living condition shape immigrants' health and that it changes over time in response to the pressures of poverty, marginalization, and class inequity. Based on this claim, how can immigrant women who are not only racialized but marginalized and more so structurally restricted by the society reap the benefit of their investment in migration? The solution will have to be the removal all the structural barriers that limit the life chances of the racialized immigrant women.

Beiser (2005) agrees that the conditions in which immigrants exist could lead to a decline in their health, and claims that, the Asian boat people went through three unique stages in the process of their resettlement in Canada: euphoria, disillusionment, and adaptation. Some authors also agreed with Beiser and claimed that the stresses of migration that typically marked the lives of immigrants are: a sense of loss, hopelessness and alienation (Choi, 1997; Mousa, 194Schneller, 1988). In addition, according to the 
study conducted by Anderson in 1997 loneliness and depression characterized the daily life of immigrant women in Canada. Loneliness as we know can lead to health problem.

In the same vein, Visandjee et.al. (2001) attribute the worsening, and the decline in immigrants' health to the stress of migration. This includes acclimatizing to Canadian culture- food and environment take their toll on immigrant women, especially those of low economic status. Affirming the foregoing, Dunn \& Dyck claim, "non-European, less well-established immigrants are particularly disadvantaged on a number of socioeconomic characteristics ... [and are] more likely than non-immigrants to report poor health status" (2000, p. 1588). For instance, studies indicate chronic health problems.

While racism has been claimed to have a negative impact on immigrant women's health, however, in the case of immigrants of colour, the harsh reality of racism and its persistence make the settlement process more difficult according to David and Collins, (1991) as cited in Cameroon et al., (1996). In addition, Kinnon (1999), claimed that poverty is also said to have a great health impact for immigrants who are women of colour as poverty results from the deskilling, under/unemployment, disruption of social ties and the lack of immediate supportive networks and indicates a high suicide rate among Asian women in Canadian study.

Immigrant women do encounter a gendered and racialized labour market that pushes most of them into low paying jobs (Creese 2005; Galabuzi 2005). The same studies cite some examples of higher rates of unemployment, lower wages, and concentrations in less desirable and more 'non-standard' jobs among aboriginal women and women of colour, compared to white Canadians. 
Census data also indicated immigrant women of colour are disadvantaged in terms of finding work and housing. Their level of poverty, research indicates impacts relatively on their health to a significant extent, according to Ornstein, (2000). Research in the united states also indicate that Women of colour are believed to be over-represented among the poor and underrepresented among the middle to high income groups, as claim by Williams, (2002). In addition, (William and Collins, 2001) indicate that, at every level of income, black women have considerably less wealth than white women.

Racism also tends to impact two determinants of income-employment and education as claimed by the Canadian Association of Social Workers (CASW) (2005). CASW further claims that even though African Canadians had equivalent or higher level of education than other Canadians they earned lower levels of income. Also, the study found that black women were more economically disadvantaged than black men. CASW cited two reasons for lower income for black women, being women and black they are therefore "in double jeopardy in terms of income. Being black, they belong to a minority whose income is among the lowest in Canada. Being, women they have less income than black men" (CASW, 2005:2).

For instance, CRIAW (2005) claimed that, according to the British Medical Journal, wealth serves as the most important driver of health worldwide, and that study after study indicate that one's income is the best predictor of health. More so, CRIAW, also claim that the more money one has, the healthier one may likely be.

CASW, then claims that, as a result of different levels of earnings, in 2000 , the average amount that black women earned was $\$ 22,278$ or $79 \%$ of black men and $57 \%$ of all men. "In terms of poverty ... in $2000,34 \%$ of black women in families were below the 
income cut-off of Statistic Canada. The incidence of black women in families who are poor is two and a half times higher than other women in families (13.7\%) and almost three times higher than men in families" (2005:10).

Racism can lead to the exclusion from the larger society, and increase immigrant women's role overload in terms of their responsibilities as nurturers according to Henry et al., (1995). They have a responsibility for providing a space within the home that is affirming and that provides a sense of belongings through cultural continuity. The notion of role overload has been documented in the US, UK, and Canadian literature as one of the defining stressors in the life of immigrant women (Anderson, 1987; Choi, 1997). In addition, Maleis (1991) asserts that immigrant women have been identified as a high risk population and their vulnerability was claimed to be stemming from the multiple roles they are required to play within the home and the external society as well as the constant negotiation of competing demands that result from their bicultural existence.

Research indicates that, there is a link between poverty and health, and that at every level of income, blacks have considerably less wealth than white women (William and Collins, 2001). Therefore, women of colour will have to contend with triple jeopardy when issues of racism and sexism are linked with issues of poverty. These experiences are not simply additive but combine to create unique and complex realities that can not be easily unpacked by class, gender, or race analysis alone. A more complex set of solutions is required for such issues as health care for poor women of colour (Mullaly, 1997; Ovadia, 2001).

Some authors claimed that white women and women with higher incomes do not have the same barriers to receiving health care as do low income women of colour. A 
review of the literature reveals that poor women of colour have been underserved by the mainstream medical community (Kumanyika, Morssink, and Nestle, 2001) They experience structural barriers to treatment which only serve to exacerbate their higher experiences of serious illness (Cooper 2002; Tharao and Massaquoi, 2001; Kumanyinka, Morssink, and Nestle, 2001).

For instance, Canada has a universal health care system to benefit all the insured population. However, with a shift in the health care system toward shorter hospital stays and more drug therapies, more health care is therefore paid privately causing huge difference in access to prescription drugs, home care, and dental care. All the alternative health therapies become unavailable to low-income earners (CRIAW, 2005).

Discrimination and segregation are both known to be part of, both, past and present experiences for many minority women. This reality, in turn, impacts on their emotional well-being with a resultant effect on their health (Pavalko, Mossakowski and Hamilton, 2002; White-Means, 2002; Tong, 2002). Racism, as well, has been identified as a cause of illness. "When people are overtly racist, it translates into poor health for the target of racism ... Structural racism leading to less income and social status has a direct impact on health" (Canadian Research Institute for the Advancement of Women (CRIAW) (2006:4). CRIAW further claim that prejudice and discrimination is likely to impact on people's health. For example some, racialized communities are said to be less likely to get jobs when equally qualified and likely to make less income. They are also likely to fall below income cut off and to have related problem like poor health.

Another example of structural racism that occurs is when standards developed in research using white men are used to measure health and health risks for women. The 
standards may not be valid for, specifically, racialized women (CRIAW) (2006). The Canadian Health Network cites Canada's Action Plan against Racism which reported that $47 \%$ of black women who took part in a Statistics Canada 2002 Ethnic Diversity Survey: portrait of a multicultural society reported that they experienced racial discrimination.

In 2005, the Canadian Association of Social Workers (CASW) carried out a study on the incomes of black women in Canada and a reported from another study which was carried out by Racism, Violence, and Health (RVH) African Nova Scotia women which claims that the women felt isolated, ill-treated, and stressed by their experiences while some indicated they had been overlooked for promotions. CASW, quoting RVH says, "racism at work whether systemic, collective, or individual contributes to several types of health problems" and concludes that health problems, in turn, adversely affect women's capacity to earn wages.

\section{THE HEALTH CARE SYSTEM AND RACIALIZED IMMIGRANT WOMEN}

In order to fully explain the declining health status of racialized immigrant women in Canada despite its universal health care system, it is important to analyse how these women are affected by "the structural barriers of sexism, racism and classism predominant in mainstream health care system" (Women's Health in Women's Hands, 2004:1). It is also believed that the barriers that a woman faces in health care will be amplified if that woman is from an oppressed group (Bayne-Smith, 1996; Adams, 1995) In addition, Bayne-Smith further claims that "non-white women suffered during this century as a result of the institutionalization of western medical model of services delivery, with its inherent qualities of racism and sexism and its insistence on singular focus on the treatment of 
disease" (1996:X1V). In the same light, Bayne-Smith also sees good health as a product of many kinds of investment that include housing, education, exercise, proper diet, selfesteem, healthy lifestyle, social support, and acceptable health care services.

Immigrant women perceived their health as being jeopardized because of the racism and discrimination they face within the mainstream health care system as claimed by Egan \&Gardener (1999). Many of the respondents in their study felt that white Canadian health care providers viewed those who were from minority groups as inferior. The women in the study spoke of how they were treated disrespectfully and in a discriminatory manner, and how they felt that their health care providers lacked an understanding of their lived reality. They felt reticent to express concerns or feelings about their health which contributed to stress and mental health problem.

Black women's anger and stress "often leads to migraine headaches, panic attack, sadness and low self- esteem" (CASW citing RVH, 2004), In addition, some authors indicate that many immigrant women have reported feeling devalued by the health care system, as well as being poorly served by the medical community that often does not understand their medical needs (Vissandjee, et. al., 2001; Kumanyinka. Morssink, and Nestle, 2001).

Bernard concludes "it is because of these multiple and interlocking oppressions faced by women of colour that their health care needs require a more holistic approach that deals with the entirety of their lives, and their material reality" (2002. p.11). For instance. women of colour are likely to experience some frustration as they have to operate within the structure of two cultures. Bayne-Smith (1996) also indicates that women of colour have to work within dominant group structures, as well as with a mind to their own world. This 
can have a serious impact in cases involving HIV/AIDS treatment for instance where a structural pharmacotherapeutic regimen based on Western notions of time and efficacy must be adhered.

Women's Health in Women's Hands (2004) undertook a study in order to assess the HIV/AIDS services available to African and Caribbean women in the Toronto area. The study found that most of the HIV/AIDS prevention, support, treatment, and care services available are delivered primarily within "mainstream" agencies/institutions. These institutions have originally been developed to meet the needs of the groups that emerged into the epidemic first-primarily men who have sex with men. (Canadian Women's Health: the Network, 2005)

Mainstream health care practitioners and counsellors can often be insensitive to the heterogeneity of non-dominant groups of women (Williams, 2002) if not overtly racist (Ali and Massaquoi, 2003: Torkington, 2002). There can be unconscious discrimination and racism in mainstream health care based on negative stereotypes of race and gender inflicted on clients and patients which will affect the care that is given to them (Williams and Collins 2001). And Eliason, (1999) claims that healthcare workers who claim to be "colour-blind" to a patient's "race" deny the unique health care concerns of women of colour.

\section{INCLUSIVE HEALTH CARE SERVICES FOR RACIALIZED IMMIGRANT}

\section{WOMEN IN CANADA}

As mentioned before, universal health care system in Canada alone is not enough to solve the health care problems of the racialized immigrant women in Canada. Their health 
care needs seem to be many hence the solution should also be seen and tackled in various ways. It is therefore important to examine the kind of health care services that will best meet the health care needs of this segment of Canadian population so that in addition to the eradication of the other structural barriers that is, those that militate against the health status of the racialized immigrant women, we will start heading to more equitable health status for all. Before going into the exploration of the inclusive health care services for the racialized immigrant women, it is important to revisit briefly the history of women's issues in Canadian history.

Historically speaking according to some authors, in the past century, women's issues came to the fore front of the national and international political agendas. Great strides have since then been made in achieving both political and social power for women in most nations world wide. However, the focus of the $20^{\text {th }}$ century women's movement has tended to lie with white, middle class women, and although progress has been made in securing equity for women in many sectors of life, there has been much criticism of women's movement's exclusion of women of colour and poor women (Marieskind \& Ehrenreich, 1975; Broom 1998; Littlefield, et. al. 2001; Jackson, et. al. 2001)

The above authors further claim that, areas in which the women's movement has made advances, as in political representation, education, and in health care are still found to be lacking in terms of representation of women of all ethnicities and socioeconomic status. Addressing issues of health care for minority women has been a recent addition to the feminist agenda, growing out of the mainstream women's health movement. Whereas the focus in the ' $60 \mathrm{~s}$ ', ' $70 \mathrm{~s}$ ', and ' $80 \mathrm{~s}$ ' for mainstream women's health equality activists 
had been the legalization of abortion but, the contemporary women's health movement has began to address the specific health care concern of poor women and minority women.

To fully address the health issues of the racialized immigrant women, they must have access to women centred health care services that operate within the feminist and antioppressive philosophy. This is necessary to provide what Jackson et. al (2001) describe as essential in addressing the specific health care needs of underserved population of women and women that have suffered oppression in various forms. Some authors assert that, by operating within the feminist and anti-racist philosophy, culturally sensitive, respectful, and quality care will be ensured and agreed that this holistic approach to health care provision is in keeping with the view that health must involve not only an understanding of woman's biology, but also of her social, political and emotional environment. (de Aguiar, 2001; Williams, 2002; Women's Health in Women's Hands, 2004).

Several authors as well assert that historically, women have not received the same quality of care as have men, and feminist based practice will enhance the commitment to promote advocacy and social change for the betterment of women's lives as this will reflect the feminist principle of empowerment. (Jones \& Ste. Croix-Rothney, 2001; Krieger \& Fee, 1994; Marieskind, 1980). In support of this, Travis \&Compton (2001) put forward that a recipe for feminist based health care must address the issues of "equality, personal experiences, context, power, inclusiveness, and activism" (p. 320). Further, as Jones and Ste. Croix Rothney (2001) state, since "Women's subordinate social position clearly has strong health effects, social change directed at empowerment and equity must be priority" (p.27). 
For the above reason, a feminist based health care must deliver services and program that are specifically designed to promote empowerment in order to improve the health status of the population served. Thomas (2002) agrees that this is important ingredient in women centred health services and outlines how feminist based health care fills a much needed void left by mainstream health care services. Thomas goes further on to assert that "the mainstream model of health care is alienating, fragmented, and acute illness-oriented and that innovation can only occur within traditional health care delivery system when providers begin to take into account individuals and the contexts of their lives, communitybased issues, and the importance of prevention" (Thomas, 2000:150).

Following the above claim, a feminist health care centre, should therefore be able to provide services that are both traditional clinical health services as well as those that are specific to the needs of the target group. A holistic model of care will enable the centre to combine medical care, counselling therapy, nutritional guidance, and educational workshop all at one location as well as providing links to outside sources. "Integrated model of care for black women and women of colour... creates healthy community of women through the integration of health promotion, education, primary health care, research, and anti-racist community advocacy" (Women' Health in Women's Hands. 2004 a, :1). Such holistic program also identify that health is a "state of complete physical, mental and social well-being and not merely the absence of diseases or infirmity" (World Health Organization, 1948:2). 


\section{CONCLUSION}

This research paper examined the decline in the health status of the racialized immigrant women in Canada based on the phenomenon that has become known as the "healthy immigrant effect. As we saw earlier, research shows that immigrant aggregated data for all immigrants are twice as likely as Canadian-born to report a deterioration in their health -that is, they had rated their health good, very good or excellent in 1994/95, but subsequently described themselves as being in fair or poor health" (Ng et al, 2005:3).

However, according to Newbold (2006), health status based on self assessment may be more apparent than real and claimed further that there is no evidence of "healthy immigrant effect" with respect to self-assessed health status, but with respect to chronic conditions which indicated that females were significantly at a higher risk than males of experiencing chronic conditions. In addition, some authors indicated a relationship between gender and immigrants' health (Chui, 2003; Hyman, 2001). They further claimed that the new research on health transition pointed to immigrant women, low-income immigrants and nonEuropeans as at higher risk of transition to poor health.

It was not possible for this paper to examine the prevalence of chronic conditions among immigrant population especially specific racialized immigrant women, due to gaps in literature. The limitation of this study is that it was based on secondary sources such as academic, and community based research. There are tensions in the clams, and there were no empirical data which makes it very 
challenging to have my questions fully answered. There is the need for more specialized finely focused study on the health of racialized immigrant women.

However, it is worth mentioning that for example, according to Beiser (1998), marginal socio-economic status does not only increase the possibility of exposure to risk factors but, compromises survival. In addition, based on the intersection theory, according to Ovadia (2001), the interaction of race, class, and gender, often result in multiple dimension of disadvantage.

In conclusion, there was a general consensus among researchers on the existence of health determinants that influence the outcome of health status, and relationship between socio-economic conditions and health. In the words of BayneSmith, "forces of race and gender clearly determine the economic, social, political, and the environmental components of class status that shape health status" (1996:3). Based on the above it could be inferred that, the racialized immigrant women who may likely be at the lower stratum of the Canadian society may also likely experience decline in their health status as a result of multidimensional factors.

Finally, women in general are not all the same neither are immigrant women, so as their health care needs. A variety of interventions is necessary to address the health care needs of the racialized immigrant women. This includes the need for additional research. As Vissandjee et al recommend. this could be achieved through the collection of "gender, ethnicity, and migration data along with other social determinants of health to create gender sensitive and culturally appropriate interventions of public health surveillance that contributes to the 
elimination of ethnic inequalities in health" (Vissandjee, B. et al 2004::9). This is most likely to help minimize both the economic and human cost of a declined health status of the racialized immigrant women. 


\section{REFERENCES}

Abbort, Pamela and Claire Wallace. (1997). An Introduction to Sociology. Feminist Perspectives $2^{\text {nd }}$ ed edition. NY: Routledge.

Adams, Diane, L. (Ed.) (1995). Health Issues For Women of Colour: A Cultural Diversity Perspective. London: Sage.

Agnew, Vijay. (1996). Resisting Discrimination. Women from Asia, Africa, and the Caribbean and the Women's Movement in Canada. Toronto: University of Toronto Press.

Allen, C. (1997). Community development for health and identity Politics. Ethnicity \& Health. 2 (3), 229-242.

Ali, A., Massaquoi, N., \& Brown, M. (2003). Racial Discrimination as a Risk for Female Youth: Implication for Policy and Healthcare Delivery in Canada. Toronto: Canadian Race Relation Foundation.

Armstrong, Pat and Hugh Armstrong. (1990). Theorizing Women's Work. Toronto: Garamond.

Armstrong, Pat and Hugh Armstrong. (1994). The Double Ghetto. Canadian Women and their segregated work. Toronto: McClelland and Stewart.

Andermahr, Sonya. Et al, Eds (2000).A Glossary of Feminist Theory. London: Arnold.

Anderson, J. M. (1999). Migration and health: Perspective on immigrant women.

Sociology of Health and Illness, vol. 9, No. 4.

Anderson, Joan. (1985) "Perspectives on the Health of Immigrant Women: A Feminist Analysis." Advances in Nursing Science, 8, 1:61-76.

Avery, Donald. (1995). Reluctant host: Canada's Response to immigrant workers, 18961994. Toronto: McClelland \& Stewart.

Bannerji, Himani. (1993). "Returning the Gaze: An Introduction." In Returning the Gaze: Essays on Racism, Feminism and Politics, ed. H. Bannerji, ix-xxix. Toronto, ON: Sister Vision Press.

Bannerji, Himani. (1987). "Introducing Racism: Towards an Anti-Racist Feminism." Resources for Feminist Research, 16, 1: 10-12

Bayne-Smith, M. (1996). Race, Gender, and Health. London: Sage. 
Beiser, Morton. (1998). "Towards a Research Framework for Immigrant Health." Presented at the Metropolis Health Domain Seminar, December 12-13, 1996. In the Metropolis Health Domain Seminar, Final Report, pp. 22-23. Ottawa, ON: Minister of Public Works and Government Services Canada, 1998.

Belanger, A. \& Caron Malentant, E. (2005). Population projection of visible minority groups, Canada, provinces and regions. Statistics Canada. Retrieved from http://www.statcan.ca/english/french/91-541-XIE/91-541-xie2005001.pdf

Bernard, W. (2002). Beyond Inclusion. In Carol Amaratunga (Ed.), Race, Ethnicity and Women's Health. (pp.1-14). Halifax: Atlantic Centre for Excellence in Women Health.

Berry, J.W., Kim, U., Minde, T., and Mok, D. (1987). Comparative studies of acculturative stress. International Migration Review, 21, 491-511.

Bolaria, B. Singh \& Bolaria, Rosemary. (1994). "Immigrant Status and Health Status: Women and Racial Minority Immigrant Workers," In Racial Minorities, Medicine and Health, ed. B. Singh Bolaria and Rosemary Bolaria, 149-1168. Halifax, NS: Fernwood.

Bolaria, B. Singh \& Peter S. Li. (1988). Racial Oppression in Canada. Toronto, ON: Garamond Press.

Bollini, P. Health policies for immigrant populations in the 1990s: A comparative studies. International Migration, vol. 30, special issue, pp. 10.

Boyd, M. (1992). Gender, visible minority and immigrant earning inequality: Reassessing and Employment Equity Premise. In Deconstructing a Nation: Immigration, Multiculturalism and Racism in '90s Canada ed. Vic Satzewich, Toronto: Garamond Press.

Broom, D. (1999). The genders of health. Paper presented at the conference "Gender, Health and Healing: Reflection on the Public-Private Divide", University of Warwick. National Centre for Epidemiology and Population Health, Australian National University.

Calliste, Agnes. (1993). Race, Gender and Canadian Immigration Policy: Blacks from the Caribbean, 1900-1932. Journal of Canadian Studies, 28(4): 131-148.

Calliste, A., Dei, G.J.S (Eds). (2000) Anti-Racist Feminism. Halifax: Fernwood Publishing.

Calvo, Janet M (1996). "Health Care Access for Immigrant." In Man Made Medicine: Women's Health, Public Policy, and Reform, ed. Kary L. Moss. 161-181. Durham, NC: Drake University Press. 
Canadian Association of Social Workers (CASW). (2005). Income of Black Women in Canada.

Canadian Council for Refugees (CCR). 1998. Best Settlement Practices: Settlement Services for Refugees and Immigrants in Canada. Montreal: CCR.

CanadianResearch Institute for the Advancement of Women (CRIAW) (2002). Fact Sheet.

Canadian Research Institute for Advancement of Women. (CRIAW) (2005). Fact Sheet.

Retrieved from http://www.criaw-

icref.ca/factsheets/racegender_e.htm\#Whatthewordmean

Carey, R. (1998). Challenging Ontario's Denial of Medical Care to HIV-Positive Immigrant. Canadian HIV/AIDS Policy and Law Newsletter, 3(2/3): 18-19

Chen, J., Wilkins, R., \& Ng, E. (1996). Health expectancy by immigrant status, 1986 and 1991. Health Report. Vol. 8, No. 3.

Chen, J., Wilkins, R., \& Ng, E. (1996). The Health of Canada's Immigrant in 1994-95. Health Reports, 7(4): 33-45.

Chui, T. and Zietsma, D. (2003). Earnings of immigrants in 1990s. Canadian Social Trends 70(Autumn0: 24-28.

Citizenship and Immigration Canada. (2000). Facts and Figures: Immigration Overview. 2001a. Ottawa: Minister of Public Works and Government Services Canada.

Citizenship and Immigration Canada. (2007), immigrating to Canada: Skilled workers and professionals http://www.cic.gc.ca/english/immigrate/skilled/apply-who.asp

Clarke, D. et al, (2002). Demoralization: its phenomenology and importance. Australian and New Zealand Journal of Psychiatry. 38(6)733-742.

Collins, P.H. (1990). Black feminist thought in the matrix of domination. Black Feminist Thought, Knowledge, Consciousness, and the Politics of Empowerment. Boston: Unwin Human.

Cooper, H. (2002). Investigating socio-economic explanation for gender and ethnic inequality in health. Social Science \&Medicine, 54, 693-706.

Creese, G. (2005). Negotiating Belonging: Bordered Space and Imagined Communities in Vancouver, Canada. Working Paper Series. Vancouver Centre of Excellence Research on Immigration and Integration in Metropolis. 
Crosby, A. To Whom Shall the Nation Belong? The Gender and Ethnic Dimensions of Refugee Return and Struggles for Peace in Guatemala: Centre for Research on Latin America and the Caribbean. CERLAC Working Paper Series.

Dunn, J., Dyck, I. (2000). Social Determinants of Health in Canada's immigrant population: Results from the National Health Survey', Social Science and Medicine, 51(11): 1573-93.

Dyck, I. (1995). 'Putting chronic Illness in "place": women immigrants' accounts of their health care', Geoforum, 26(3): 247-60.

Eagan, C., \& Gardner, L. (1999). Racism, Women's Health and Reproductive Freedom in Dua, E. \& Robertson, A. Scratching the Surface: Canadian Anti-Racist feminist thought. Toronto.

Epp, J. (1986). Achieving Health for All: A Framework for Health Promotion. Canadian Journal of Public Health. 1986: 77(6): 393-424.

Epp, Marlene, Franca Iacovetta, Frances Swyripa, eds. (2004). Sisters or Strangers? Immigrants, Ethinic, and Racialized Women in Canadian History. Toronto: University of Toronto Press.

Estable, Alma. (1986). Immigrant Women in Canada: Current Issues. A background paper prepared for the Canadian Advisory Council for the Status of Women. Ottawa.

Finch, B.K., Kolody, B., and Vega, W.A. (2000) Perceived discrimination and depression among Mexican-origin adult in California. Journal of Health and Social Behaviour 52: 571-583.

Galabuzi, G. (2001). Canada's Creeping Economic Apartheid: The Economic Segregation and Social Marginalization of Racialised Groups. Toronto: The CSJ Foundation.

Grant, Judith. (1993). Fundamental Feminism. Contesting the Core Concepts of Feminist Theory. NY and London: Monthly Review.

Gushulak, Brian. (.2007). Healthier on arrival? Further insight into "healthy immigrant effect". Commentary: Canadian Medical Association, 176(10).

Health Canada. (1999). Canadian Research on immigration and Health. http://dsppsd.pwgsc.gc.ca/collection/H21-149-1999E.pdf

Henry, Frances \& Effie Ginberg. (1985). "Who Gets the Work? A Test of Racial Discrimination in Employment. Toronto, ON: Social Planning Council of Metropolitan Toronto and Urban Alliance on Race Relation, January 1985. 
Hooks, Bell. (1984). Feminist Theory: From Margin to Center. Cambridge, MA: South End Press.

Hooks, Bell. (1989). Talking Back: Thinking Feminist, Thinking Black. Toronto: Between the Lines.

Hooks, Bell. (2000). Where We Stand: Class Matters. New York: Routledge.

Humphries, B. (2003). What else counts as evidence in evidence-based social work? Social Work Education, 22(1) 81-91.

Hyman, I. (2001). Immigration and Health. Working Paper 01-05. Health Policy Working Paper Series. Ottawa: Health Canada. September. http://www.hc-sc.gc.ca/iacbdgiac/arad-draa/english/rmdd/wpaperslhtml.

Jackson, S., Camacho, D., Freund, K., Bigby, J., Walcott-McQuigg, J., Hughes, E., Nunez, A., Dillard, W., Weiner, W., Weitz, C., \& Zerr, T. (2001). Women's health centres and minority women: Addressing barriers to care. The National Centres of Excellence in Women's Health. Journal of Women's Health and Gender Based Medicine, 10 (6), 551-560.

Jasso, G., Massey, D., Rosenzweig, M.R., and Smith J. (2003). Immigrant Health: Selectivity and Acculturation. Santa Monica, Ca: RAND.

Jiwani, Yasmin (1994). "Women of Colour and Poverty." Occasional Working Paper in Women's Studies and Gender Relation, 3, 1 (1994): 1-15.

Kazemipur, A., and S. Halli (2000). The invisible barrier: Neighbourhood poverty and integration of immigrants in Canada. Journal of International Migration and Integration, vol. 1 , No. 1.

Kelley, Ninette., and Trebilcock, Michael. (2000). The Making of The Mosaic: A History of Canadian Immigration Policy. Toronto. University of Toronto Press.

Kinnon, D. (1999). Canadian research on immigration and health: An overview. Ottawa: Health Canada.

Kopec, J., Williams, J., T., \& Austin, P. (2001). Cross-Cultural comparison of health status in Canada using the Utilities Index. Ethnicity \& Health. 6 (1). Ottawa: Health Canada.

Krieger, N., ET AL. (1993). Racism, sexism and social class: implication for studies of health, disease and well-being. Am J Prev Med 9(S6):82-122.

Kumanyika, S., Morssink, C., \& Nestle, M. (2001). Minority women and advocacy for women's health. American Journal of Public Health, 91 (9). 1383-1387. 
Kymlicka, W. (1995). Multicultural Citizenship: A liberal theory of minority rights. Oxford University Press.Kymlicka, W. (2001). Politics in the vernacular: Nationalism, multiculturalism and citizenship. Oxford; Oxford University Press.

Laroche, M. (2000). "Health Status and Health Services Utilization of Canada's Immigrant and Non-Immigrant Population.' Canadian Public Policy, 26(1): 5173.

Lawson, E., Rodgers-Rose, L., \& Rajaram, S. (1999). The psychosocial context of black women's health. Health Care For Women International, 20, 279-289.

Leath, B. (1995). Homeless Children. In Diane Adam (Ed.), Health Issues for Women of colour. A Cultural Diversity Perspective. (pp. 208-227). London: Sage.

Li, P.S. (2003). Destination Canada: Immigration debate and issues. Toronto: Oxford University Press.

MacKinnon, M. \& Howard, L. (2000). Affirming Immigrant women' health: Building Inclusive health policy. Final Report. Halifax, NS: The Maritime Centre of Excellence for Women's Health, May 2000.

Marieskind, H.I (1980). Women in the Health Care System: Patients, Providers and Program. Toronto: The C.V. Mosby Company.

McDonald J.T. \& Kennedy, S. (2004). Insights into the "healthy immigrant effect": health status and health services use of immigrants to Canada, Social Science and Medicine, 59(8): 1613-27.

McIntosh, P. (1990). White privilege: Unpacking the invisible knapsack. Independent School, 49 (2), 33-36.

Meleis, A.I (1997). Immigrant transition and health care: an action Nursing Outlook, 45(1) 42.

Milan, A., Tran, K. Blacks In Canada: A Long History, Canadian Social Trends. Statistics Canada. Spring 2004.

Moussa, Helene. (1994). Challenging Power Together: A Handbook to Set up and assess Support Groups for and with Immigrant and Refugee Women: Education Wife Assault. Toronto, $\mathrm{ON}$.

Mullaly, B. (1997). Structural Social Work. New York: Oxford University Press.

Mulvihill, M. A., L. Mailloux and W. Atkin (2001). Policy and Research Responses to Immigrants and Refugees Women's Health in Canada. Winnipeg: Canadian Women's Health Network. 
Ng, E., Wilkins, R., Gendron, F., \& Berthelot, J.M. (2005). Dynamics of Immigrants' health in Canada: Evidence from the National Population Health Survey. Ottawa: Statistics Canada. Catalogue No. 82-618MWE2005002.

$\mathrm{Ng}$, Roxana. (1986). The Social Construction of Immigrant Women in Canada. Roberta Hamilton and Michele Barrett, Eds. The Politics of Diversity. Montreal: Book Centre, Inc.

Ng, Roxana. (1990). Immigrant Women: The Construction of a Labour Market Category. Canadian Journal of Women and the Law, 4(1): 96-112.

Ng, Roxana (1993). "Racism, Sexism, and Immigrant Women." In Changing Patterns: Women in Canada, ed. S. Burt, L. Code \& L.Dorney, 279-301. Toronto, ON. McCelland \& Stewart, 1993.

Neuman, W.L. (1997). Social research method: Qualitative and quantitative approaches. Needham Heights, MA: Allyn \& Bacon.

Newbold, K. Bruce. (2006). "Chronic conditions and the healthy immigrant effect: evidence from Canadian immigrants." Journal of Ethics and Migration Studies, 32(5): $765(20)$.

Ocran, A.A. (1997). "Across the Home/Work Divide: Homework in Garment Manufacture and the Failure of Employment Regulation." In Challenging the Public/Private Divide. Feminism. Law \& Public Policy, ed. S.B. Boyd, 144-167. Toronto, ON: University of Toronto Press, 1997.

Ontario Council of Agencies Serving Immigrants (OCASI). Immigrant Women and Health- OCASI Presentation.

Ornstein, N. (2000). Ethno-racial inequality in the city of Toronto: An analysis of the 1996 census. Toronto: Access and Equity Unmet.

Ovadia, Seth. (2001). "Race, class, and gender differences in High School Seniors" Values: Applying Intersection Theory in Empirical Analysis". Social Science Quarterly. 82(2) 341-56.

Pavalko, E.K., Mossakowski, K.N., \& Hamilton, V. (2003). Does perceived discrimination affect health and longitudinal relationship between work discrimination and women's physical and emotional health. Journal of Health and Social Behaviour. 44(1), 18-33.

Pentland, H.C. (1960). Labour and Development of Industrial Capitalism in Canada. University of Toronto Press, Toronto. 
Perez, C.E. (2002). 'Health Status and health behaviour among immigrants', Supplement to Health Reports. Statistics Canada, Catalogue 82-003-SIE, 1-12.

Powles, J., Giggord, S. (1990). How healthy are Australia's immigrant? In Reid, J, Tromp P. eds. The health of immigrant Australia: a social perspective. Sydney: Harcourt Brace Jovanovich.

Reid, P.T. (2000). Women, ethnicity and AIDS: What's love got to do with it? Sex Roles $42(7 / 8), 709-723$.

Robert, Barbara. (1990). Immigrant Woman: Triple Jeopardy. Presentation given at the opening meeting of the Simone de Behaviour Institute Research Seminar (19871988): Immigrant Women/La femme immigrante. Collection 'Working Papers/Inedits' 3. Montreal, QC: Publication of Simone De Beauvoir Institute.

Ruzek, S.B. (1978). The Women's Health Movement: Feminist Alternatives to Medical Control. New York: Praeger.

Saloojee, A. (2003). Social inclusion, anti-racism and democratic citizenship. Working papers Series: Perspective on social inclusion. Toronto: Laidlaw Foundation.

Schimmele and Wu. (2004). The Healthy Immigrant Effect on Depression: Variation Over time. University of Victoria: BC Canada.

Schneller, Dedora Podolsky. "The Immigrant's Challenge: Mourning The Loss of Homeland and Adapting to the New World." Studies in Social Work.

Shadd, A. (2003). Institutionalized racism and Canadian history: Notes of a Black Canadian. In Carl E. James (Ed), Seeing ourselves: Exploring race, ethnicity and culture ( $3^{\text {rd }}$ edition, pp165-170). Toronto: Thompson Educational Publishing Inc.

Shamsuddin, Abul F.M. (1997). The Double-Negative Effect on the Earning of ForeignBorn Females in Canada. Vancouver Centre of Excellence. Research on Immigration and Integration in the Metropolis. Working Paper Series, \#97-04.

Sherwin, Susan. (1998). The Politics of Women's Health: Exploring, Agency, and Autonomy. Philadelphia: Temple University Press. Statistics Canada. (2001). Census: Analysis Series, Canada's ethnocultural portrait-the changing mosaic. Ottawa: Statistics Canada, Operations Division.

Statistics Canada. (2004). 'The National Population Health Survey: 1994/95 to 2002/03', The Daily, November 24.

Statistics Canada. (2006). Women in Canada: A Gender-Based Statistical Report. The Daily, March 7. 
Stover G. (2002). Colourful communities: toward a language of inclusion. Am J Public Health, 92(4):512-14.

Thobani, Sunera. (1998). "Nationalizing Citizens, Bordering Immigrant Women: Globalization and the Racialization of Women's Citizenship in Late $20^{\text {th }}$ Century Canada." Doctoral Dissertation, Department of Sociology \& Anthropology, Simon Fraser University, 1998.

Thomas, Jan E. (2000). Incorporating empowerment into models of care: Strategies from feminist women's health centres. Research in the Sociology of Health, 17, 139152.

Tong, R. (2002). Love's labour in the health care system: Working toward gender equity. Hypatia, 17, 200-216.

Torkington, N. P.K. (1995). Black migrant women and health. Women's Studies International Forum, 18 (2), 153-158.

Travis, C.B. and Compton, J.D. (2001). Feminism and Health in the decade of behaviour. Psychology of Women Quarterly, 25, 312-323.

United Nations. (2004). The Best Place to Live in the World. (UN) Human Development Index.

Vega, W.A. B. Kolody, J.R. Valle. (1987). "Migration and Mental Health: An Empirical Test of Depression Risk Factors among Immigrant Mexican Women." International Migration Review 21, 3 (1987): 512-529.

Vissandjee, B., Weinfeld, M., Dupere, S., \& Abdool, S. (2001). Sex, gender, ethnicity, and access to health care services: Research and policy challenges for immigrant women in Canada. Journal of International Migration and Integration, 2 (1), 5575.

Vissandjee, B. et al. (2004)..Integrating Ethnicity and Migration as Determinants of Canadian Women's Health. BioMed Central BMC Women's Health 4(S1-S32) 1472-6874. Retrieved from http://bmc.ub.unipotsdam.de/1472-6874-4s32/text.htm

White-Means, S.I. (2002). The colour of health and health care. Business Perspectives, 14 (4), 16-21.

Williams D.R. (2002). Racial/ethnic variations in women's health: The social embeddedness of health. American Journal of Public Health, 92 (4), 588-597.

Williams D.R., \& Collins C. (2001). Racial segregation: A Fundamental cause of racial disparities in Health. Public Health Reports. 116, 404-416. 
Women's Health in Women's Hands. (1998). Policy, Procedure and Protocol Manual. Toronto: Women's Health in Women's Hands.

World Health Organization. (1948). Geneva, Switzerland.

World Health Organization. (1986). Ottawa Charter on Health Promotion. Copenhagen: World Health Organization Regional Office for Europe.

Zlotnik, Hania (2003). The global dimensions of female migration. Migration Information Source.

Zulman, Arthur. "The Hidden Trauma of Immigration." Australian Family Physician, 25, 11 (November 1996): 1707-1710. 